\title{
Adrenal Cancer pN1 TNM Finding v7
}

National Cancer Institute

\section{Source}

National Cancer Institute. Adrenal Cancer pN1 TNM Finding v7. NCI Thesaurus. Code C89408.

Adrenal cancer with metastasis in regional lymph node(s). (from AJCC 7th Ed.) 